\title{
Popularity of Literary Malay Magazine after the Second World War
}

Hamedi M.A ${ }^{1}$

Ezaleila S.M1

Saleeh M.R ${ }^{1}$

Zaliza N.S1

Wahid A.J2

\begin{abstract}
${ }^{1}$ Department of Media Studies, University Malaya, Kuala Lumpur, Malaysia
\end{abstract} 2 SKET, University Malaya, Kuala Lumpur, Malaysia; hamedi@um.edu.my

Doi:10.5901/mjss.2015.v6n5s1p560

\section{Abstract}

Various genres in modern literature can be found in the early Malay magazines. Even in the non-literary magazines, those elements were norms, be it in original or in translation forms. The elements were used as supplements to relay the message indirectly or to give readers some sort of amusement and easy reading of entertainment materials. Twenty one literary magazines were published after the Second World War until the Independence in 1957. Using the first two copies of these magazines, the study content analyses the element of literary works which include of poems, short stories, humor stories, anecdotes, and serialized novels. Besides, historical and official records were also negotiated as well as interviews with publishers and editors of those magazines who are still alive. The study among others found that literary magazine play a dominant role to raise the spirit of nationalism besides being used as a platform for enrichment of Malay literary works. In addition, a profile of the Malay literary magazine after the Second World War will be presented in this article.

Keywords: Malay magazines; publishing; journalism; Malay literature; short stories

\section{Introduction}

The first Malay magazine specifically accommodates for fiction and creative work is Chahaya Bintang (Starlight). Published in Seremban on 1 December 1926, the magazine is edited by Abdul Hamid Mohamad and published by AlRauthah Press. However, the magazine only appeared three issues and ceases its publication when the publisher goes for pilgrimage to Mecca (Muhammad, 1941:57). Himself a writer, the editor allocated mostly short story in his magazine, although other general materials such as education, witty and question-answer of educational issues were also appeared. In its first issue, the whole of 16 pages in Chahaya Bintang was filled with a story entitled "Setia Persahabatan" (Loyal Friendship).

Obviously, most of early literary magazine were operated by individuals who have a tendency of writing. Two of the most important among them was Mohd Ariffin Ishak and Asa'ad Shukri Muda. Mohd Ariffin Ishak and his wife, Aminah Abdul Jalil has published Majalah Cherita (Magazine of Story) in November 1938. By using the name of Pen Publishing Company, this magazine accommodated seven to eight short stories in each issue and most of the stories were in continue for several issues (Hamedi, 2002:78). However this magazine could only survived for nine issues.

Mohd Ariffin also played a big role in the establishment of Sahabat Pena (Pen Friends) in Penang where members quickly grew as a result of a campaign made by him and other supporters through Saudara (Brother), the leading newspaper in the state. Persaudaraan Sahabat Pena Malaya (PASPAM) or Malayan Pen Friend Brotherhood was established in September 1934 as a result of suggestion by the editor of Saudara, Syed Alwi Al-Hadi that provide a space in the newspaper from 7 April 1934 for this literary organization. Early leaders for PASPAM are Sheikh Abdullah AlMaghribi who also involved in the other newspaper, Bumiputera (Indigenous), Nyak Mohd Amin, Syed Abdul Rahman AlYahya, C.M. Ibrahim and Zainal Abidin. the objectives of PASPAM are to foster friendship among its members, encouraging its members to write and write in Malay, and set up a Malay library. The first conference of this organization was held in Taiping and in 1935 its membership were exceed 2,000.

PASPAM published a monthly Pemberita Pejabat PASPAM (Newsletter of PASPAM Office) in 15 June 1938 while 
its branch in Singapore issued Suara Pena (Voice of Pena) in 1 September 1938, which later replaced by Pancharan Pena (Pen Magazine, since 1 May 1939). In February 1940, Teman PASPAM (Paspam's Friends) was established as a platform for members to publish their works as well as to voice their opinion on literary issues. Unfortunately, PASPAM activities ceased following the war and only in 1949 an attempt were made to revive it by Jimmy Asmara although it was less successful. The organization enjoyed its peak times in 1938 when over 12,000 people registered as its member. At this point, Pemberita Pejabat Persaudaraan Sahabat Pena Malaya or Pemberita Pejabat Paspam was published as an official publication of the association. It publishes news, reviews, opinions, and original literary works for association members and those who are interested. Later in 1940, Ariffin also edit an annual association magazine, Teman Paspam, which unfortunately could only be published once before the outbreak of the Second World War.

The study of literary works in Malay periodicals was done by Omar (1961), Li (1967) and Hashim (1982). All of them were agree that magazine has played a very important role as a medium of literary works, particularly in the form of short stories. Another researcher, Kamaruzzaman (1982) focused his study on the publication of poetry by Malay newspapers and magazines during the Japanese occupation. In addition, several other studies were conducted by researchers who focus on the role of a particular newspaper or magazine in the publications of literary works. Among them are Roff (1972) who did mentions on this important role, especially in the period before the war where he characterizes the decade of the 1930s as a big "flood" in Malay literature. On the other hand, Ismail (1959) investigated the concentration of Singapore as a base for Malay literary activities shortly after the war, while Abdul Aziz (1959) examined the development of publications in Singapore in the period after the war.

A literary magazine is a periodical devoted to literature in a broad sense. Literary magazines usually publish short stories, poetry and essays along with literary criticism, book reviews, biographical profiles of authors, interviews and letters. Generally, literary magazine is dominantly contained of fiction such as short story, poem, pantun (rhythmatic verses), etc. and non-fiction which related to critics and feature of literary scene. The term periodical is used to describe any publication which is issued on a regular and continuing basis-weekly, monthly, quarterly, or at some other stated interval. From the studies presented, it appears that the literature has played a very important role in the Malay magazine publishing after the war. While this study will prove the truth of the premises, the tendency on how the popularity of literary elements could become an integral part of the Malay magazine publishing after the war will also be discussed.

\section{The Popularity of Literary Magazine}

Studies on literary magazines in Britain (Parker, 2004) and in America (Chielens, 1992) are generally concentrated on the status of the medium itself. Parker argued that literary magazine should be an object of study in their own right, and explored the ways in which literary magazine begin to frame a discussion of Romanticism. To analyse, he developed two key terms, context and politics. Context can mean the immediate environment of the other contributions in a given number of a magazine. Context can also be produced by the relation between editor and contributor; overtly in the commissioning of a particular article or essay, in negotiation about the product, and through editorial changes. For politics, Mark studied literary magazines which "surprisingly clear and self-conscious meditations on politics considered in the largest sense, as having to do with the national as a whole" (p.2). On the other hand, Chielens (1992: 43) argued that the medium, i.e. the magazine which published literary materials played more important role in shaping the popularity of the literary itself.

Popularity of literary magazine depends on the editorial staff which made up of talented, creative, and prolific young writers. They are able to edit the short stories to suit the reader's interest. In general, many readers are interested in reading the stories since the magazine is the only medium afford by them. Such magazines can be purchased cheaper than radio-a major rival for print media at that time. Television media still unknown to the Malay society, while movies are confined to towns and cities, and also at a particular time. The magazine can be read at any desired time, compared to radio where the broadcast schedule is set by the producer. Thus, only by reading material, especially magazines can be used as a passport to the reader to explore the world of imagination and fantasy as well as a mix of reality world expressed in it.

However, readership for literary magazine is not much compared to entertainment magazine. Compared to circulation for entertainment magazine which achieved dozen thousand copies per issue, circulation for literary magazine is around 3,000 to 5,000 copies. Fortunately, many of them are faithful and loyal readers, while entertainment magazines rely so much on pictures or issues to attract purchases. Loyalty to literary magazine greatly aided by the tendency of readers to the field of writing and literature. Interest in writing and literature are quite unusual at the time (Roff, 1975:168). Not only do many magazines or newspapers survived because the interests of readers to this literature, but variety of associations or clubs that support the aspirations of its own were set up in a greater number. 
Persaudaraan Sahabat Pena which was already died due to the break of Second World War was revived in 25 August 1949, headed by Jaafar Muhammad or Jimmy Asmara. Originally it was used by Jimmy, a prolific writer, to connect with his Heiho (local youth who acted as Japanese military assistant) friends to maintain friendships with each other. The move is clearly well received, even from the other young men who wanted to friendship with Jimmy through literature. As a result of his efforts, Jimmy managed to get a space in a literary magazine, Hiboran as a platform to this organization. In general, Sahabat Pena aims to get to know each other, exchange ideas, and mutually respect (Li, 1967:159).

In Singapore, the associations oriented to literature and culture is actively emerge and sink, such as Malay Language Board, Literary Force of ' 50 or Asas ' 50 , and later, New Malay Literary Force. Lembaga Bahasa Melayu was established in 1 October 1950 and its registration was confirmed on 26 April 1951. Asas ' 50 was established on 6 August 1950 as a result of a meeting of 19 young writers at the home of one of a writer, Mas in Henderson Road. The objectives of Asas ' 50 as outlined in its constitution are to expand and upgrade the Malay literature and culture, protect the rights of all its members and all writers, and to reforms in the literature (Li, 1967:161-64).

Most of the Asas ' 50 members consist of Malay youth in Singapore with a total of 99 members in 1954. Among the main founders are Keris Mas, Asraf, Mas, Hamzah, Jamil Sulong, Jimmy Asmara, Awam-il-Sarkam, and Masuri SN Meanwhile, Angkatan Persuratan Melayu Baru established in 17 April 1954 as a result of the split that occurred in Asas '50. Hamzah, who championed the concept of "Art for Art's Sake" in Asas '50 differ with most of other member who believed in "Art for the People". The contradiction was finally spilt the Asas '50. Hamzah pulls out of the organization together with other members such as Aeby Muara, Amin Jaya, Abdul Salam Ayub, M.S. Haliza, and Abdul Ghani Hamid who together set up a new organization, Angkatan Persuratan Melayu Baru. However, this organization was hardly active, mainly because of the busy schedule of Hamzah himself as an officer at Cathay Organization which reduce his involvement in writing and literary.

In Kedah, an association, Lengkongan (Sphere) appeared with its own magazine, also named Lengkongan in November 1955. In Malacca, Mohd Yusuf Harun through Malacca Malay Literature Bond publishes three magazine, Tunas Sastera (Literary Bud) in March 1954, an annual Taman Bahasa (Language Garden) in 1955, and Kebudayaan (Culture) in December 1955, despite all are relatively short life. The bond was established on 17 November 1950 by a handful of Malay intelligentsia interested in Malay literature. The organization led by Mohd Yusuf Harun not only accepts members from Malacca, but also from Negeri Sembilan, Johor and Selangor. The goal of this organization is to combine writers around the southern region for the sake interest of language, literature, and the desire of the people to get independence from the colonial.

The emergence and the continuity of literary magazines in this period greatly aided by the fact that the readers themselves who are interested in this field. Accordingly, the contribution played by several writers is dominant enough to carry the flag of literature in Malay magazine. Among them were Harun Aminurrashid, Ishak Muhammad, A. Samad Ismail, who should be considered as veteran, and young writers like Keris Mas, Rosmera, Adi, Usman Awang, Arenawati, Jimmy Asmara, Hamzah, Masmera, Hamdam, Edrus, Wijaya Mala, Mas, Rayuan Sukma, and Abdullah Hussain. The authors mentioned are in average young, pretty prolific, and really interested in their field for them to improve their works to satisfy readers. Their presence in Malay literary is often stimulates novice readers to this field and to follow in their footsteps to be a writer or a poet.

\section{Harun Aminurashid and the Emergence of Hiboran as a Literary Magazine}

The first Malay magazine dedicated specifically for literary works is Hiboran (Entertainment) which published in January 1946. Published by Abdullah Ally at the Royal Press Ltd, North Bridge Road, Singapore, this digest magazine was actually in danger for closing in its early times. Talib, the manager of Royal Press felt Hiboran circulation of 500 copies is not viable and make preparation to close the magazine. Furthermore the editor, Mahmud Ahmad was asked to manage Benih, a new educational magazine for Malay schools to be published by the education department. Mahmud was introduced to Harun Aminurrashid who just returned to Singapore after his contract as a supervisor of education in Brunei was not renewed by the government. He challenged Harun to prove his ability by preparing the copy of Hiboran's tenth issue, a task that successfully done by Harun in only a day. It was here the turning point of the golden touch by Harun Aminurrashid who became the dominant figure for Malay magazine after the War. Since Hiboran in 1946, he edited and published not less than 10 magazines and two newspapers in Singapore.

Hiboran itself successfully developed as a leading digest literary magazine. From a monthly magazine, the frequently change to bi-monthly in March 1947, and later became weekly from July 1948. It started with the motto "Contains stories, poems, general knowledge and others" in 1946, before changed to "The Leading Malay Fortnightly 
Magazine" a year later and to "The Main Weekly Magazines in Malaya" in 1949. Beginning in 1950 the motto changed to "The Top Malay Weekly Magazine" and to "The Weekly Literary and General Knowledge" in 1955 until its publication ceased in September 1958.

The first editor of Hiboran is Mahmud Ahmad or Wiwaha who after four issues was replaced by M. Yusof Lana. He was replace by Harun Aminurrshid when the publisher was about to cease its publication. Harun managed to improve the magazine and transformed it as a leading literary Malay magazine. Harun handed over the magazine to Abdul Jalil Noor in September 1950 to become the chief editor of the company which also published other magazines such as Kenchana (Gold), Dewan Pujangga (Poet Hall), Hiboran Cherita (Stories for Entertainment), Hiboran Film (Films for Entertainment), Seni (Art), Mutiara (Pearl), Tunas (Bud), Fashion, Belia (Youth), Dunia (World) and Kesah (Story). Other writers who have become editors of Hiboran were Rawan Hiba, Abdul Majid Hussin, Arenawati, Adi Mas, Hamzah, and Aeby Muara. The popularity of Hiboran was described as follows by an author:

Hiboran is indeed a popular magazine and liked by many. I have seen some young readers are discussing to find words to be filled in words puzzle of the magazine. Virtually all are enjoy reading its short stories. Women and girls are often use radio program schedule for radio guide. Movie enthusiasts love to read and see the pictures of actor and actress. There are people who cut the cover of Hiboran magazine for the pictures to be stored in an album. Several others are copying biography of figures, poets, and famous people to be kept. Some took the opportunity to find pen pals with readers who have posted their photos. From this evidence it is clear Hiboran is in line with its motto as "The Leading Malay Weekly Magazine (Mim, 1948).

Besides Mastika (The Magazine) which was more respected at that time, the life of Hiboran is the longest among literary magazines in this period. Hiboran plays an important role in nurturing and developing talent of young authors and used as a stepping stone for them for a higher platform of Mastika or Utusan Zaman (Time Envoy). Despite the dominant content of literature, Hiboran also published other writings such as human interest, women, and biographies of great people, culture pages, and poetry. As an encouragement to young readers, pictures of girls with passion were also published. As the name implies, the goal of the magazine "... is none other than to provide entertainment to gentlemen readers, male and female, young and old, even children" (Jan 1950:4).

When Hiboran provide a platform to Sahabat Pena, Jimmy Asmara who takes care of the column managed to attract many young Malays to join literary organization. From 600 members on 18 August 1951, members of Sahabat Pena who sent biodata and photograph to be published in Hiboran increased to 1,200 in 22 March 1952 and this development directly help improve the circulation of the magazine. Before that, in September 1950, Abdul Jalil Noor replaced Harun Aminurrashid as the editor of the magazine while the later continues to be the magazine's advisor. These changes had to be made because Harun have to bear an additional burden upon the commencement of Malayu Raya Press where he himself became the manager of the company.

Young writers from around the corner of Malaya and even from overseas continue to contribute to Hiboran. Among them were Hamzah, Rosmera, Nur Alhadi, Alimin, Mas, Mim, Syamak, Wijaya Mala, Norma Kedah, Perlis Syamim, Qalam Al-Mahmudi, Osman Abdullah, Mashor Malaya, Rayuan Sukma, Kamariah, Masuri S.N., Norma Kamaruddin, Cenderawasih, Fatimah Perlis, and Adibah Amin. Hamzah then himself sits on the editorial board of Hiboran. Among contributing author from abroad are Muhd Ibrahim Alham (Mengkasar), Yura Halim (Brunei), Hasyim Abdullah (Baghdad), and Syamsul Haq (Mesir). Beginning in January 1952, Hiboran starts paying honorarium to the contributors.

The digest size of Hiboran enlarged to $7.5 \times 10.3$ inches from 10 April 1954. Its cover pictures also become increasingly bold with pictures of Western actress with seductive style to attract readers. This rather drastic action is done to compete with film entertainment magazines such as Bintang (The Star), Utusan Film \& Sports (Film \& Sports Envoy), and Film Raya (Great Films) who began stealing Hiboran readers. By enlarging the size, Hiboran will be able to compete with other magazines in bookstores. The picture quality was is also improved, better produced on glossy paper.

As a consumer product, publisher of Hiboran is aware that the magazine should meet the tastes of readers. The question is, is it enough to enable the magazine survived in the market? Over 12 years after the war consumer are presented with so many magazines with their own specialty, each are trying to win the hearts of readers. However, out of 145 magazines published during those periods (Hamedi, 2003), very few are able to survive more than three years, let alone survive for more than 20 years in the case of Hiboran.

The short lived magazines were also trying to attract readers by manipulating their respective editorial contents. But of course, just dress up and seduce the readers with attractive contents will not guarantee the successful of magazine. There are other factors, not merely the product or contents, but also the economy, culture, passion, and so on which to combine for the survival of the magazine. Hiboran was lucky enough to be published by a printer, Royal Press. The magazine is printed within the company which is owned and operated by a family enterprise headed by Abu Talib Ali. Harun Aminurrashid admitted that the fact that Hiboran is self-published by a printer was a key factor for it to survived 
quite long (Hiboran 10 Years, 1956:18).

During the consultation process to lead Hiboran at the end of 1946, Harun Aminurrashid acquainted with Raja Mohd Yusof Ahmad, owner of Al-Ahmadiah Press. The acquaintance become friendly and Harun managed to influence Raja Mohd Yusuf to co-establish a publishing and printing company, named Harmy, the initial for both of them. Harmy first project is publishing a magazine which contains short stories, later named Dewan Pujangga in July 1948.

Despite claiming a monthly magazine, Dewan Pujangga is not published on a regular basis. To keep the magazine from quickly stale in the market, no reference date is given, only the numbers. Three months later, Harmy publishes another literary magazine, Mutiara in October 1948. Mutiara published as a direct rival to the two major literary magazines, Mastika and Hiboran. Harun Aminurrashid himself leads the editorial of Mutiara before handed it over to three young editors, Abdul Jalil Nor, Abu Zaky Fadzil, and Abdullah Salleh, who manages the editorial of the magazine until 1956, when they were accompanied by M.S. Haliza and Dahlan Buyong or Arenawati.

Its first issue stated that, "Mutiara is specially published to contain short stories. Mutiara will not change its policy of prioritizing content with short stories that build the society. This is a firm policy of the magazine" (Mutiara, October 1948, p. 3). Also stated that "... the content of Mutiara is mainly short stories in all parts of life such as about education, spy stories, knowledge, society and a continuous story in a row... We will also publish poems from young poet and every issue will be filled with story life of great persons to mirror our life."

In addition to short stories, the magazine is also accommodating editorial column, romance of the society, biography of the world poet, comics, detective stories, and film reviews. Initially, it gave priority to detective or romance stories, and human interest stories like strange and unusual happenings. Inevitably, the content of Mutiara was largely influenced by Hiboran which also led by Harun Aminurrashid. The tendency of Hiboran to publish more pages on comics and humor and later catchy pictures can also be traced in Mutiara. It may effect to the increase of circulation of the magazine from 1,500 copies in 1950 to 3,000 copies in October 1951 (Hamedi, 2003:89).

Prior to that, Harun Aminurrashid at Royal Press which publishes Hiboran also published another literary magazine, Hiboran Cherita in December 1949. Hiboran Cherita uses the motto "The Main Weekly Magazines in Malaya" and edited by Harun Aminurrashid himself. Initially the magazine sold at to RM0.25 a copy before it was increased to RM0.30 in May 1950. Generally it published short stories with accompanied with photographs which normally not related at all. Stated in the first issue that the magazine "contain with short stories which have been refined and written by young well known writers." This magazine is stimulated by a good response to Hiboran. Published originally as a bi-monthly, it was changed to weekly since February 1950. However, it ceased its publications soon after the publisher increasingly aware of their unwise move to provide internal competition to the more popular magazine, Hiboran.

Quite sometime after that, in August 1956, Harun Aminurrashid and Royal Press reissue another literary magazine, Kesah that complements to Hiboran. Kesah is published as a monthly, and it normally contains of 10 short stories. It uses a motto "Monthly Short Story" with a sub-motto "Compiled with Latest Literary Development. It was stated that the magazine "contain of short stories. We published with the purpose of providing opportunity for members of the Malay literature community who love to write short stories" (August 1956: 3). In the first issue among short stories published are "The sea ghost killer" by Arenawati, " The final separation" by Kasturi, "The unfortunate widow" by Masmera, "A Dramatic Scene of Romance" by R. Alida, "Poor" by Hamzah, and "Ribbed and stained" by Harun Aminurrashid.

Magazines edited or supervised by Harun Aminurrashid are usually get a good response from the reader. The magazines published by renowned publisher at the time. Royal Press, a publisher that gives journalistic life to Harun Aminurrashid has existed since before the war and became one of the main Malay printers in Singapore. Books and magazines it published distributed widely as Royal Press has a well-established network of agents due to its relatively large amount of backlist. Harmy on the other hand, depends to Al-Ahmadiah Press. It emerged as a popular publisher because of a lot number of magazines and literary it published. Besides Kesah, it also published Mutiara, Tunas, Fashion, Belia, and Dunia.

\section{The Role of Mastika}

The most important magazines that publish literary works is Mastika which formerly known before the Second World War as Mustika. First published in 1 November 1946, this magazine in general published stories, humor, human interest, and articles of religious, social, and historical issues with accompanied with pictures. But short stories and literary writings dominate the pages of the magazine. The content is filled specifically by the editorial staffs of the magazines such as Hamdam and Edrus, and then, Keris Mas as well as contributing authors from all over Malaya.

The magazine uses the motto "Malay Monthly Publication" in 1946 before changed to "Leading Malay Monthly Publication" two years later. Among the editors who worked on this magazine are Abdul Rahim Kajai (Jun-Dec 1941), 
Hamdam and Edrus (1946-48), Kamaluddin Mohammad (1948-53), Asraf Abdul Wahab (1953-55), and Usman Awang (1950-62). At the beginning (1941) this monthly magazine contains writings for general reading knowledge and politics before transformed into literary magazine after the war because of the reader's interest at that time. This magazine is one of the longest survived Malay magazines in the market, published since 1941 and survives until today. The magazine is experiencing significant changes in concept over its publication. In the early stage this magazine tend to provide political and general knowledge writings, before turning to literature in 1950, education in the 1970s, digest general knowledge in 1980s before turning to academic-popular in the decade of the 90s, and finally, since 1995 changed to digest of human interest (Harun, 1959; Rohaya, 1999).

The monthly published Mastika was certainly more respected than weekly Hiboran, partly due to the highly image of its publisher, Utusan Melayu Press Ltd. among the Malay readers. They also published a daily newspaper, Utusan Melayu (Malay Envoy) which is said to be the first newspaper financed by the Malays (Zainuddin, 2013: 56) and a weekly Utusan Zaman. Seen as the voice of Malay society, Utusan Melayu since its first edition on 29 May 1939 is indeed seen as a benchmark for Malay journalism, at least until the end 1970s when its popularity faded and replace by romanced script Utusan Malaysia, also published by the same media group. The image of the newspaper by itself influenced the magazine, as both newspapers could be used as an effective platform to promote the magazine. However, in terms of support from writers, Hiboran looks strong, especially with the presence of young writers under the leadership of the famous author, Harun Aminurrashid. However the digest form for Hiboran and sometimes its exploitation to sensation and sex is quite disfiguring its image. The magazine may attract young and budding writers to contribute their writings, while the established and star authors pay more attention to Mastika. On the other hand, the image of Mastika was not affected, although Keris Mas in his experiment to bring reform to the magazine in 1948 changed the concept of cover with pictures of beautiful women.

Mastika continues to be a respected literary magazine until after independence and as mentioned by Keris Mas, the young writer was then used the magazine, apart from Utusan Zaman as a target to achieve their satisfaction in literature. Hiboran, Mutiara, Juita, and other magazines that published literary works, usually used as a stepping stone for their works to get published in Mastika (Kamaluddin, 1979:60). To maintain the image Mastika was more selective, do not simply publishes any literary works received from contributing authors. Stories published in the magazine were carefully selected, meticulously edited, and must always related to Malay society. The stories of fantasy and delusion, has long been gradually abandoned... we aim to reach the top of Malay literary development and the advancement of the Malay mind" (Jan 1950:3).

In preservation of its image, the magazine was always aware of the need of the readers. If the publisher is not responsive to the current tendency, Mastika should have immediately shut down at the end of 1940's, when Utusan Melayu Press had suffered a loss as a result of the publication of the magazine. Keris Mas took over as the magazine's editor when the magazine was at a critical position. Before leaving for London for a visit sponsored by the British government, the Utusan Melayu head, Yusof Ishak gave an ultimatum that the magazine was to be closed if circulation is not improved. Keris Mas who was appointed to replace Edrus and Hamdam tried to save the magazine. He changed the concept of the magazine to contain only short stories and with full colour of art paper cover. The picture in the cover are consists of local or international actress (Kamaluddin, 1979:63).

For Keris Mas, changes have to be made to save the magazine. A. Samad Ismail and Tengku Hassan who are assigned to manage Utusan Melayu Press in the absent of Yusof had to agree with Keris even though they doubt that such a recipe would be successful. Keris Mas fills Mastika with short stories either of romance or detective stories with a pseudonym Mr. X, and translation of romance stories. Fortunately, it turns out that is what is required of the reader. The magazine circulation slowly improved. Later in 1949, the magazine began to open its pages to the element of entertainment, in particular issues related to movies. Photographs of actress and film scenes were increased. Mastika is modified to provide short stories with the needs of readers to be relaxed while reading it by having photographs of actress decorated the pages.

As an incentive to author, Mastika was started paying honorarium beginning in January 1951. Stated that: "A good news for Mastika's contributors is our move to provide some consolation for the authors of the writings (including short stories and essays) we consider should be given honorarium (money) provided the essay was published by Mastika and the honorarium is assessed by our own" (Mastika, January 1951:5). From March 1952, Mastika organized a short story contest by offering a first prize of RM100, second RM60, RM40 for third, and five consolation prizes of RM10 each. The contest attracted 224 short stories and three grand prizes were secured by Nasha with the story "Dissent", Asmar with "Promise", and Asni the story "Asiah Cry Again".

Under the leadership of Keris Mas Mastika managed to build its own image as a reputable literary magazine. It pages coveted by writers to see their work published. However, with current interest of short stories has waned, and 
responsive to the desires of readers, led Asraf who replaced Keris Mas when the later joined daily newspaper, Melayu Raya, to change the concept of the magazine. Short stories still continue to be published, but the numbers are reduced. In this new concept, Asraf said:

... Every month, in average we present two short stories, an article on language, an article on the literature, one on cultural, one translation of a short story, one or two poems and others ... so it is our contribution to the culture as a whole (Dec 1954:4).

\section{Other Literary Magazines}

In addition to private publishers who usually are also printers, certain individuals with deep interest in Malay literature are also published literary magazine. Among them is Abdul Ghani Abdullah in Kuala Pilah which published Juita (Lovely) in September 1948 and later added another one in 1954 with Jambangan Juita (Lovely Bouquet). Juita generally publish short stories (each issue contains three stories) and general knowledge writings. Among regular column in the magazine are literature, short stories, general knowledge, columns on religion, and photographs. Stated in its first issue that the purpose of this magazine is to "train children to write" besides to fill the "urgent need for magazines and newspapers that provide fundamentals of Islam and Islamic spiritual upbringing" (Sept 1948:5). As such the publisher hopes for "our kids to know Islam, history, their duties of knowing modern education to progress in the future and encourage them to broaden their knowledge."

The concept is not much different between Juita with Hiboran and Mutiara. Physically it is also very similar to the two magazines, except Hiboran which is digest-shaped. Hiboran experienced three significant changes in the size of 6.8 x 9.5 inches in 1946 to digest $5 \times 7$ inches in 1949, and to $7.5 \times 10.3$ inches in January 1954. In terms of frequency, Hiboran started as a monthly before changed to bi-monthly in March 1947 and to weekly from July 1948. Juita published by Abdul Ghani Abdullah at The Sentausa Store which located in Kuala Pilah. Ghani personally led this magazine, assisted by Ahmad Bakhtiar before then relinquish the editorship to Afrini Adham in 1951 and to Abdul Majid Abdul Wahab in the following year. The illustration was done by Saidin Yahya.

Juita managed to last quite a long time on the market and is mostly due to the determination from Ghani himself who handle problems arising due to the remote location of Kuala Pilah from the center for Malay magazine in Singapore. The main problem to be faced is its location in the small town of Kuala Pilah. Since the authors and editors of the magazine are in place apart, rather than in the same town, their relationship with Ghani is done by mail. This problem often ends up with the delayed publication of Juita.

After Juita ceased its publications in 1954, Ghani introduced Jambangan Juita as a replacement. Stated that the magazine is "published for providing entertainment... and also be friends while alone... Apart from entertainment news and short stories, Jambangan Juita will take some news or story around the community because of the lack of medium for it" (1954:3). Also stated that "pictures of actress in this magazine is nothing to do with the stories published, only the photos were meant solely for entertainment or purely decorative..." Publisher is hoping that this magazine will release the thirst for reading." The magazine is edited by Salleh Ghani and published news and short stories accompanied with pictures, usually from the film scene and provocative pictures of actress. The common editorial materials are short stories and critique to the society.

Other magazines, mostly offered short stories continue to be published, including those related to the literary organizations. Among them are Kebudayaan (Culture in July 1952, Tunas Sastera (Mar 1954), and Taman Bahasa (Aug 1955) published by Ikatan Persuratan Melayu Melaka. Other literary magazines are Sahabat Pena (November 1952) by Persaudaraan Sahabat Pena, Lengkongan (Nov 1955) by Lengkongan Pemuda-Pemuda, Kebudayaan (Culture) (Dec 1955) by Kesatuan Kebangsaan Guru-guru Sekolah Umum Persekutuan Tanah Melayu, and Bahasa (Language) (Feb 1956) by Malay Federation of Malaya University.

Kebudayaan is the first magazine published by Malacca Malay Literary Bond. Edited Mohd Yusuf Harun, this magazine contains variety types of writing of language, culture, and literature, as well as on religion. However, the digest magazine has only appeared once. At the same time, the group also published two other literary magazines, Taman Bahasa and Tunas Sastera. The editors involved in the first issue were Ishak Abdul Ghani, Aziz Tapa, Abdul Samad Ahmad, Abu Samah Leman, Abdul Majid Elias, Bachek Ismail, Said Suit, and Mohd Saleh Daud. This magazine contains writings on such creative short stories and poetry, as well as articles on culture and language. Questions about the development of literature were also raised in Tunas Sastera.

Lengkongan (Sphere) was published in Butterworth by A. Rahman Dahlan on behalf of The Sphere of Young. The bi-weekly magazine of 16 pages is contains with writings on language, short stories, women, pen pals, hobbies, friends, 
identifying closely, gifts, children, the general plan, and poetry. Stated that "... to fill the pages of magazine with the things that can satisfy readers would only be filled by Lengkongan friends from various organizations around the archipelago" (Dec 15 1955:3).

Kebudayaan (Culture) is published in Muar, Johor by The National Union of Public School Teachers' Federation of Malaya. The magazine is led by Ahmad Abdul Rahman and edited by Johari Alias. This magazine generally published writings on culture, religion, art, literature, poetry, short stories, history, and news of the union, even though specialization is on culture. In its first issue stated that "Apart from being made as a voice for Malay Teachers' Union Other Training Federation of Malaya, the magazine is aimed at trying to raise the standard of literary and culture for particular to its members, and to the people in general" (Dec 1955:3).

Bahasa is a scholarly journal published by the Federation of Malay Language University Malaya. Among those the editor was Ali Ahmad (1956) and Ismail Hussein, Ismail Anbia, Kassim Ahmad, Omar Mohd Hashim, Mohd Yusuf Hussein, and Alis Murni (1957). This magazine is not consistently published, and it last version was number 6 (1964/65), which was led by Ismail Hussein and Mohd Yusuf Hussein. In general, this magazine contains a variety of types of writing on issues of Malay language, culture, and literature written in scholarly or popular approaches. Most articles are written and produced by students and academic staff of Department of Malay Studies, University of Malaya.

When Malaya gained independence, a government agency set up to develop the Malay language and literature, the Dewan Bahasa dan Pustaka (DBP) are making their way to publish a magazine. Its first magazine is Dewan Bahasa (Sept 1957) and led by Kamaluddin Mohammed or Keris Mas which previously been edited Mastika at the end of the decade of the 40s and early 50s. Originally this magazine is filled with articles of a general nature regarding the language, literature, and culture. In his foreword, the Director of DBP, Syed Nasir Ismail stated that the purpose of this magazine is to provide a platform for all views, opinions, thoughts, and research results about the Malay language. In addition, the magazine is expected to accommodate creative works and issues of Malay literature. In the first issue it was stated that "the articles contributed from outside DBP if requested, received and published in the magazine will be offered an honour payment of RM25.00 to RM75.00 each. Similar will be paid for unsolicited articles. These include anything relating to language, literature and criticism concerned with literature, book reviews, short stories, and so on. Poem will be paid according to the quality" (Sept 1957:3).

Unless Dewan Bahasa, all magazines mentioned are short-lived due to the small number in circulation and as a result, they could not managed to attract advertisement. Furthermore those magazines had to compete with other more reputable magazine by established publishers who was anchored by some popular authors at the time. The major magazines were Mastika, Hiboran, and Mutiara as well as Juita. Moreover, most newspapers available at that time such as Utusan Zaman, Warta Mingguan, Warta, Mingguan, Melayu, Merdeka, and Warta Masharakat had also provide regular pages for literary works.

\section{Conclusion}

Our observations found 21 Malay literary magazines published in the period after the Second World War until Malaya gained Independence in August 1957. Most magazines published works of prose, especially short stories, whether in original forms or those translated from other languages, especially from English and Arabic. The large number of literary magazines and in addition with other periodicals which also published literary works, raises questions about the exploitation of literary works in Malay periodical publishing. Do literary works deliberately published because that was the kind that interests for most reader or do those materials are just reflection of editors who habitually inclined in writing for his own satisfaction?

Based on the circulation and longevity of literary magazine published, it appears that the later assumption is not true. Such magazines have itself a significant audience, the literary enthusiasts which immense the number of overall readers available. While the circulation of literary magazines is less than entertainment oriented magazines, the fact that their relatively long life-span suggest the viability of this magazine. This may be due to the loyalty of readers to the literary magazines. They are more likely to make a consistent purchases once the magazines published, as opposed to entertainment magazines that depend on the issues highlighted. Literary magazines generally too dependent on editorial element to enable it to survive in the market, while the other elements in magazine publishing-circulation and advertising -are not able to help. The circulation is relatively lower; at around 2,000 to 5,000 copies and the ability to attract advertisers are also quite limited. Fortunately the number of literature devoted fans is a lot and it helps literary magazines to survive in the market, and even some last up to ten years. 


\section{References}

Abdul Latiff, A.B. (1986). Abdul Rahim Kajai: Journalist and Malay author. Kuala Lumpur: Dewan Bahasa dan Pustaka.

Ali, A. (1975). Majallah Guru: The magazine of the Malay Teachers (with particular reference to the 1924-1932 periode and the role played by Muhammad Yusuf Ahmad. Ph. D Thesis, Monash University.

Arenawati (1980). Short story in Japanese era. Kuala Lumpur: Pustaka Antara.

Chielens, Edward E. (1992). American literary Magazines: The eighteenth and nineteenth centuries. New York: Greenwood.

Hamedi, M.A. (2002). Directory of Malay magazine before the Independence. Kuala Lumpur: University Malaya Press.

Hamedi, M.A. (2003). Development of magazine in Malaysia. Shah Alam: Karisma.

Harun, D. (1959). The contents of Mastika (A leading Malay monthly magazine) from 1946-1956. Graduation exercise, Department of Malay Studies, University Malaya.

Hashim, A. (1982). Malay short stories before Second World War. Kuala Lumpur: Dewan Bahasa dan Pustaka.

Ismail, H. (1959). Singapore as a Malay literary centre after World War II. Graduation exercise, Department of Malay Studies, University Malaya.

Kamaluddin, M. (1979). 30 years of literary scene. Kuala Lumpur: Dewan Bahasa dan Pustaka.

Kamaruzzaman, A.K. (1982). Nationalism and modern Malay poem 1933-1957. Kuala Lumpur: Dewan Bahasa dan Pustaka.

Li, C.S. (1967). History and development of modern Malay literary. Kuala Lumpur: Pustaka Antara.

Mim (1948). Hiboran and me. Hiboran, 27 July.

Muhammad, S.H. (1967). Mastika: Its role as a literary Malay magazine after World War II. Graduation exercise, Department of Malay Studies, University Malaya.

Omar, M.H. (1961). Development of Malay short stories before World War II. Dewan Bahasa, Ogos.

Parker, Mark (2004). Literary magazine and British romanticism. Cambridge: Cambridge University Press.

Roff, W.R. (1972). Bibliography of Malay and Arabic periodicals published in the Straits Settlements and Peninsular Malay States $1876-$ 1941. London: Oxford University Press.

Rohaya, M.A. (1999). Mastika: development and contents. Graduation exercise, Department of Media Studies, University Malaya.

Zainuddin, M. (2013). The history of Utusan Melayu. Kuala Lumpur: Utusan Melayu Press. 